\title{
An Evaluation of Vitek MS System for Rapid Identification of Bacterial Species in Positive Blood Culture
}

\author{
Kang-Gyun Park ${ }^{1}$, Sang-Ha Kim ${ }^{2}$, Jong-Tae $\mathrm{Choi}^{3}$, Sunghyun Kim ${ }^{4}$, Young-Kwon Kim ${ }^{5}$, Young-Bin Yu ${ }^{5}$ \\ ${ }^{1}$ Department of Laboratory Medicine, Seoul St. Mary's Hospital, College of Medicine, The Catholic University of Korea, Seoul, Korea \\ ${ }^{2}$ Department of Laboratory Medicine, Konyang University Hospital, Daejeon, Korea \\ ${ }^{3}$ Department of Biomedical Laboratory Science, Kyungdong University, Gangwondo, Korea \\ ${ }^{4}$ Department of Clinical Laboratory Science, College of Health Sciences, Catholic University of Pusan, Busan, Korea \\ ${ }^{5}$ Department of Biomedical Laboratory Science, College of Medical Sciences, Konyang University, Daejeon, Korea
}

\section{혈액배양 양성검체에서 패혈증 원인균 신속동정을 위한 Vitek MS 시스템의 유용성 평가}

\author{
박강균 ${ }^{1}$, 김상하 $^{2}$, 최종태 ${ }^{3}$, 김성현 ${ }^{4}$, 김영권 $^{5}$, 유영빈 ${ }^{5}$ \\ ${ }^{1}$ 가톨릭대학교 서울성모병원 진단검사의학과, ${ }^{2}$ 건양대학교병원 진단검사의학과, ${ }^{3}$ 경동대학교 임상병리학과, ${ }^{4}$ 부산가톨릭대학교 보건과학대학 \\ 임상병리학과, ${ }^{5}$ 건양대학교 의과학대학 임상병리학과
}

\begin{abstract}
The aim of this study was to shorten the time required for subculture and bacterial identification and obtain a simple and rapid identification method for new test methods for bloodstream infections. The following results were obtained using a mass spectrometer. In Vitek 2, 208 (81.8\%) cases were well-identified and 45 isolates were not identified in blood cultures. Among 208 cases, 146 (57.5\%) were Gram positive bacteria and 108 (42.5\%) were Gram negative bacteria. In total, 233 were identified to the species level and 21 were identified to the genus level. The identification error was found to be Propionibacterium acnes as Clostridium bifermentans. The accuracy of Enterobacteriaceae, glucose non-fermentative bacilli (GNFB), and staphylococci were 81/83 (97.6\%), 12/15 (80.0\%), and 72/85 (84.7\%), respectively. The concordance rate of Vitek 2 and Vitek MS by the direct method was $81.8 \%$ and 45 isolates were not identified. Most of the unidentified bacteria were Gram positive bacteria ( $N=37)$. The Gram positive bacteria were streptococci (14), coagulase-negative staphylococci (CNS) (11), enterococci (3), Staphylococcus aureus (2), Micrococcus spp. (2), Bacillus spp. (2) and Actinomyces odontolyticus, Finegoldia magna, and Peptostreptococcus spp. The results reporting time was reduced to $24 \sim 72$ hours compared to the conventional method. The rate of identification of the aerobic and anaerobic cultures was similar, but the use of an anaerobic culture did not require a dissolution process, which could shorten the sample preparation time. These results suggest that the method of direct identification in blood cultures is very useful for the treatment of patients. In further studies, it might be necessary to further improve the method for identifying streptococci and CNS, which were lacking in accuracy in this study.
\end{abstract}

Key words: Bloodstream infection, Direct identification, Positive blood culture, Rapid identification

This is an Open Access article distributed under the terms of the Creative Commons Attribution Non-Commercial License (http://creativecommons.org/licenses/by-nc/4.0) which permits unrestricted non-commercial use, distribution, and reproduction in any medium, provided the original work is properly cited.

Copyright ( 2017 The Korean Society for Clinical Laboratory Science. All rights reserved.
Corresponding author: Young-Bin Yu Department of Biomedical Laboratory Science, College of Medical Sciences, Konyang University, 158 Gwanjeodong-ro, Seo-gu, Daejeon 35365, Korea Tel: 82-42-600-6379 Fax: 82-42-600-6565 E-mail:ybyoo@konyang.ac.kr

Co-Corresponding author: Young-Kwon Kim Department Biomedical Laboratory Science, College of Medical Sciences, Konyang University, 158 Gwanjeodong-ro, Seo-gu, Daejeon 35365, Korea Tel: 82-42-600-6371 Fax: 82-42-600-6565 E-mail: ykkim3245@konyang.ac.kr

Received: November 3, 2017 Revised $1^{\text {st: }}$ November 15, 2017 Revised 2 ${ }^{\text {nd }}$ : November 21, 2017 Revised $3^{\text {rd. }}$ : November 28, 2017 Revised $4^{\text {th. }}$ : December 5, 2017 Accepted: December 6, 2017 


\section{서 론}

패혈증은 다양한 감염증을 동반할 수 있고, 여러 종류의 세균 이 원인이 되어 나타나기 때문에 그 원인균을 규명하기 위해 혈 액배양이 필수적이다[1]. 미국의 경우 매일 2천명 이상의 새로 운 환자가 발생하며 사망률이 30 50\%로 매우 높은 질환이다 [2].

중증 패혈증은 패혈증과 함께 저혈압, 장기부전, 조직 관류 저하가 동반되는 상황으로 정의된다[1]. 패혈 쇼크는 적절한 수 액 치료에도 수축기 혈압 $90 \mathrm{mmHg}$ 이하 혹은 평균 동맥압 65 $\mathrm{mmHg}$ 이하를 동반하는 경우를 말한다[1,3]. 최근의 한 연구에 따르면 중증패혈증 환자들의 성별 사망률은 남성과 여성이 각 각 $66.4 \%$ 와 $62.9 \%$ 이며 $70.3 \%$ 는 패혈증의 원인균에 의한 것으 로 보고 되었다[4]. Kumar 등은 패혈증을 진단하고 1시간 내에 항균제로 치료하면 환자의 생존 확률이 $80 \%$ 이상이지만, 6 시간 이 지난 후에는 생존율이 $30 \%$ 를 넘지 않는다고 보고하였다[5]. 그러나 현재까지도 명확한 패혈증의 신속 진단법이 없어 원인 균을 알기 위해서는 24 시간 이상 혈액배양을 해야 하는데 배양 하는 동안에도 환자의 생존 확률은 급격히 떨어진다.

현재 혈류감염의 원인 미생물을 검출하기 위한 표준검사 방 법은 상용화된 액체배지를 이용한 자동화된 혈액배양 시스템에 의한 혈액배양검사이다. 자동화된 혈액배양 시스템을 사용하 면 양성 배양 병을 시스템에서 꺼내고 배지 일부분을 고체배지 에 계대배양 시켜 육안으로 관찰되는 집락이 형성될 때 까지 최 소 12 시간에서 최대 48 시간이 소요된다[6,7]. 배지에서 독립된 집락을 채취하여 정해진 농도에 맞추어 자동화 동정 장비에서 24시간 검사하면 패혈증의 원인균을 동정할 수 있지만, 최종보 고까지 48시간에서 72 시간이 소요된다.

배양시간을 단축하기 위해 개발된 matrix-assisted laser desorption ionization-time of flight mass spectrometer (MALDI-TOF MS)는 검체와 매트릭스가 혼합된 결정체에 레이 저를 조사하여 이온화시킨 후, 전하를 띤 이온들을 비행시간형 (Time of Flight) 질량분석(mass spectrometry)기에 통과시켜 검출기까지의 도달시간을 측정하여 분자량을 분석하는 장비로 최근 이 기기가 다양한 미생물의 동정을 위해 임상 미생물 검사 실에 도입되었다. 이 장비는 몇 분 안에 세균과 효모종을 동정할 수 있지만 18 48시간 배양된 독립된 집락이 필요하다[8]. 이전 의 방법들은 에탄올, 포름산, 아세토니트릴[9] 또는 노동 집약적 용해 여과법[6]을 사용하거나 그람음성 막대균만을 평가하는 제한점을 갖고 있었다[10]. 질량분석기를 이용하여 혈액배양 양성 검체에서 계대배양 없이 세균을 직접 동정하고자 하는 연
구들이 시도되었지만[11] 본 연구에서는 혈액배양 양성 검체에 서 계대배양 없이 세균의 직접 동정을 시도하고 이 연구에 사용 된 방법이 기존의 표준방법과 비교하여 신속도, 신뢰도와 정확 도를 비교 평가하고자 하였다.

\section{재료 및 방법}

연구에 사용된 검체는 서울 소재 1300 병상 규모의 C 종합병 원에 입원한 환자의 혈액배양 검체 중 양성으로 확인된 254개 의 혈액 배양액을 대상으로 하였다. 혈액배양액에서 채취한 시 료는 Vitek 2를 이용한 표준방법으로 세균 동정을 진행하였으 며, 혈액배양액에서 직접 Vitek MS (bioMérieux, Marcy L'Etoile, France)시스템으로 세균을 동정하여 그 유용성을 평 가하였다.

\section{1. 혈구 용해액 제조}

본 실험에서는 세균의 생존에 전혀 영향을 주지 않으면서 가 격이 저렴하고 신속하게 혈액의 세포 성분을 파괴하여 제거할 수 있는 두 가지 성분인 염화암모늄 용액과 사포닌 용액을 혼합 하여 빠르고 신속하게 용해되는 용해액의 농도와 적절한 반응 시간을 찾고자 하였다. 첫째, 사포닌 농도에 따른 시간별 적혈 구, 백혈구의 용해 여부를 확인하였다. 적혈구, 백혈구 측정은 Neubauer chamber로 시행하였다. 둘째, 각 농도별 세균의 생 존 여부를 확인하였다. 두 가지 실험을 바탕으로 본 연구에서는 $9.26 \%$ 염화암모늄 용액 $(0.1 \mathrm{~mL})$ 과 $2 \%$ 사포닌 용액을 혼합하여 사용하였다.

\section{Vitek 2 시스템을 이용한 표준 세균 동정}

혈액배양 용기가 BACTEC FX (Becton Dickinson, USA) 시 스템에 의해 양성으로 확인 되 었을 때, 배양용기에서 검체를 채 취하여 그람염색과 계대배양을 실시한 후 혈액우무배지(Asan BAP I; Asan Pharmaceutical, Seoul, Korea)와 맥컨키우무배 지(Asan Mac II; Asan Pharmaceutical, Seoul, Korea)에 각각 $100 \mu \mathrm{L}$ 씩 접종하여 계대배양하였다. 배양 후 고형배지에 형성 된 세균 집락들은 Vitek 2 시스템의 Gram Positive card (GP card; bioMerieux), Gram Negative card (GN card; bioMerieux), Anaerobic card (ANC card; bioMerieux) 그리고 Neisseria, Haemophilus card (NH card bioMerieux)를 사용 하여 동정하였다. 


\section{3. 혈액배양 양성배양액에서 Vitek MS를 이용한 직접동정}

검체 준비 방법은 혈액배양의 종류(무산소성 배지와산소성/ 소아용 배지)에 따른 차이가 있었는데, 그 이유는 무산소성 배지 에는 사포닌 성분 $(0.26 \% \mathrm{w} / \mathrm{v})$ 이 포함되어 있어 용해 단계가 생 략되었기 때문이다. 무산소성 배지의 경우, 양성 혈액배양병에 서 $10 \mathrm{~mL}$ 를 채취하여 $15 \mathrm{~mL}$ 의 튜브에 넣고 $4,500 \times \mathrm{g}$ 에서 3 분 간 원심분리하고, 상층액을 버리고 남아있는 침사에 $0.45 \%$ $\mathrm{NaCl}$ 로 2회 세척하고, 마지막으로 $0.45 \% \mathrm{NaCl} 10 \mathrm{~mL}$ 에 현탁 시켜 나일론 메쉬 $(66 \mu \mathrm{m}$ 의 공극 크기)로 세포 파편을 제거하였 다. 필터 처리한 현탁액은 $4,500 \times \mathrm{g}$ 에서 3 분간 원심분리하고 침사는 $0.45 \% \mathrm{NaCl}$ 에 재부유하였다. 위에서 만들어 놓은 현탁 액 $100 \mu \mathrm{L}$ 를 $1.5 \mathrm{~mL}$ 의 마이크로 튜브에 넣고 $15,000 \times \mathrm{g}$ 에 3 분 간 원침하였다. 상층액을 제거하고 침사가 있는 튜브에 $20 \mu \mathrm{L}$ 의 에틸알코올을 넣고 강하게 혼합하여 검사용 표적슬라이드 (Vitek MSDS, bioMerieux)에 1 2 $\mu \mathrm{L}$ 를 떨어뜨리고 실온에서 건조하였다. 건조한 표적슬라이드에 $1 \mu \mathrm{L}$ 의 $\mathrm{CHCA}$ matrix 용 액( $\alpha$-cyano-4-hydroxycinn amic acid solution, bioMerieux) 을 점적하고 실온에서 건조하였다. 건조 시킨 표적슬라이드를 질량분석기인 Vitek MS를 이용하여 동정하였다. 산소성/소아 용 배지는 적혈구와 백혈구를 용해하기 위하여 용해 단계인 염 화암모늄 용액 $1 \mathrm{~mL}, 5 \%$ 사포닌 용액 $5 \mathrm{~mL}$ 를 침사와 섞은 후 10 분 방치가 추가 되었다. 스펙트럼 분석을 위해 Vitek MS IVD system v2.0을 사용하였고 결과는 제조자가 제공 한 라이브러 리 v2.0과 비교하였다. 스펙트럼은 대장균(Escherichia coli, ATCC 8739)을 사용하여 정도 관리를 시행하였다. Vitek MS에 서 표적슬라이드의 결과 값이 $90 \%$ 이상의 신뢰 수준을 보였을 경우 유효한 결과로 사용하였다.

\section{4. 통계 분석}

분리 세균의 동정은 고형배지에서 계대배양하여 Vitek 2 시 스템을 사용한 표준방법과 Vitek MS 시스템을 사용한 혈액배양 직접법이 동일한 결과를 얻으면 식별이 정확하다고 간주하였 다. Vitek MS 시스템을 사용한 혈액배양 직접법의 결과와 표준 방법의 결과와 다른 결과를 보이는 경우, 동정은 부정확 (misidentification)한 것으로 간주하였다. Vitek MS 데이터베 이스에 시험한 세균의 스펙트럼과 일치한 것이 없으면 시험 균 주의 결과는 "no identification"으로 하였다. 표적 슬라이드에 점적한 검체의 상태가 좋지 않아 Vitek MS 시스템의 스펙트럼 피크가 충분히 나오지 않을 땐 "bad-spectrum" 또는 "peaks not enough"이라는 경고 메시지가 나오면 "no identification"
으로 하였다. 혈액배양병에 따른 평가는 산소성/무산소성병의 성능을 통계적으로 비교하기 위해 Chi-square test 또는 Fisher's exact test를 사용하였다.

\section{결 과}

\section{1. 혈액배양에서 Vitek 2를 이용한 표준동정과 MALDI-TOF $\mathrm{MS}$ 를 이용한 직접동정의 결과 비교}

혈액배양에서 한 가지 세균종만 배양된 검체는 총 254 개였 고 이 중 그람양성 세균이 배양된 검체가 146 개, 그람음성 세균 이 배양된 검체가 108 개였다. 배양된 세균들을 Vitek 2 를 사용 하는 표준방법으로 시행하였을 때, 233 검체는 종(species) 수 준까지 확인되었고, 21 검체는 속(genus) 수준까지 동정 되었 다. MALDI-TOF MS를 이용한 혈액배양 직접 동정 결과와 Vitek 2를 사용하여 표준방법으로 검사한 균주의 동정 결과를 비교하였다(Table 1, Table 2).

전체적으로 Vitek 2는 208주(81.8\%)의 세균을 정확히 동정

Table 1. Comparison of results between the direct method (Vitek MS) and the standard method (Vitek 2) for identification of Gram positive bacteria

\begin{tabular}{lcc}
\hline \multicolumn{1}{c}{ Microorganisms } & VITEK2 & VITEK MS (\%) \\
\hline Staphylococcus aureus & 36 & $34(94.4)$ \\
Staphylococcus epidermidis & 23 & $18(78.3)$ \\
Staphylococcus haemolyticus & 12 & $9(75)$ \\
Staphylococcus capitis & 8 & $5(63)$ \\
Staphylococcus hominis & 4 & $4(100)$ \\
Staphylococcus saprophyticus & 1 & $1(100)$ \\
Staphylococcus cohnii spp. & 1 & $1(100)$ \\
urealyticus & & \\
Enterococcus faecium & 23 & $21(91.3)$ \\
Enterococcus faecalis & 6 & $5(83.3)$ \\
Streptococcus mitis/oralis & 8 & $3(38)$ \\
Streptococcus parasanguinis & 2 & $0(0)$ \\
Streptococcus viridans group & 2 & $0(0)$ \\
Streptococcus pneumoniae & 2 & $1(100)$ \\
Streptococcus gallolyticus spp. & 1 & $0(0)$ \\
pasteurianus & & $0(0)$ \\
Streptococcus constellatus spp. & 1 & \\
$\quad$ constellatus & & $0(0)$ \\
Streptococcus salivarius & 1 & $0(0)$ \\
Streptococcus mutans & 1 & $1(100)$ \\
Streptococcus anginosus & 1 & $1(33.3)$ \\
Micrococcus spp. & 3 & $1(33.3)$ \\
Aerococcus urinae & 1 & $3(75)$ \\
Propionibacterium acnes & 4 & $0(0)$ \\
Bacillus spp. & 2 & $0(0)$ \\
Actinomyces odontolyticus & 1 & $0(0)$ \\
Finegoldia magna & 1 & \\
Peptostreptococcus spp. & 1 & \\
Total & $146.9 \%)$ \\
\hline
\end{tabular}


하였고, 45주는 동정되지 않았다. 동정 오류 검체는 Propionibacterium acnes를 Clostridium bifermentans로 잘못 동정 한 한 건이 발생하였다. 정확하게 동정된 208주 중 196 (94.2\%) 주는 종수준까지 동정되었고, 12 주는 속 수준까지 동정되었다. 그람염색 결과에 따르면 그람양성 세균에서는 108 (73.9\%)주, 그람음성 세균에서는 100 (92.6\%)주가 동정되었다.

균종별 정확도는 Enterobacteriaceae, glucose nonfermentative bacilli (GNFB), staphylococci의 정확도는 각각 81/83 (97.6\%), 12/15 (80.0\%), 72/85 (84.7\%)로 나타났다. Vitek MS에서는 45주가 동정되지 않았고, 그 중 29주는 "bad spectrum"경고 메시지로 인해 동정되지 않았으며, 9주는 "not-identified"으로 하였으며, 7주는 "not enough peaks"라 는 경고 메시지가 표시되고 동정되지 않았다. 동정되지 않은 세

Table 2. Comparison of results between the direct method (Vitek MS) and the standard method (Vitek 2) for identification of Gram negative bacteria

\begin{tabular}{lcc}
\hline \multicolumn{1}{c}{ Microorganisms } & VITEK2 & VITEK MS (\%) \\
\hline Escherichia coli & 53 & $53(100)$ \\
Klebsiella pneumoniae & 14 & $13(92.9)$ \\
Salmonella spp. & 3 & $3(100)$ \\
Enterobacter cloacae & 4 & $4(100)$ \\
Enterobacter aerogenes & 3 & $3(100)$ \\
Klebsiella oxytoca & 3 & $3(100)$ \\
Serratia marcescens & 1 & $1(100)$ \\
Pantoea spp. & 1 & $0(0)$ \\
Providencia stuartii & 1 & $1(100)$ \\
Pseudomonas aeruginosa & 10 & $10(100)$ \\
Acinetobacter baumannii & 2 & $0(0)$ \\
Stenotrophomonas maltophilia & 2 & $2(100)$ \\
Burkholderia cepacia & 1 & $0(0)$ \\
Ralstonia mannitolilytica & 3 & $1(33.3)$ \\
Chryseobacterium indologenes & 1 & $0(0)$ \\
Haemophilus influenzae & 1 & $1(100)$ \\
Bacteroides fragilis & 2 & $2(100)$ \\
Clostridium tertium & 2 & $2(100)$ \\
Neisseria spp. & 1 & $1(100)$ \\
Total & $108(100 \%)$ & $100(92.6 \%)$ \\
\hline
\end{tabular}

균들의 대부분은 그람양성 세균(N=37)이었고, 그람양성 세균 은 streptococci (14), coagulase-negative staphylococci (CNS) (11), enterococci (3), Staphylococcus aureus (2), Micrococcus spp. (2), Bacillus spp. (2) 그리고 Actinomyces odontolyticus, Finegoldia magna, Peptostreptococcusspp.가 각각 1 건씩이었다.

직접 전처리 방법에 의한 산소성 및 무산소성 배양의 정확한 동정율은 각각 149/182 (81.8\%) 및 127/145 (87.6\%)이었다 $(p=0.742)$. 산소성 및 무산소성 배양병에서의 그람양성 세균의 정확한 동정률은 각각 $76.2 \%$ 및 $77.4 \%$ 이었다 $(p=0.960)$. 산소 성 및 무산소성 그람음성 세균의 정확한 동정률은 각각 $88.8 \%$ 및 $97.3 \%$ 이었다 $(p=0.783) .33 / 182$ 개의 산소성 배양병과 $17 / 145$ 개의 무산소성 배양병에서는 세균이 동정되지 않았다 ( $p=0.221$. 또한 53 개의 산소성 배양과 90 개의 무산소성 배양은 "no growth."으로 표시되었다. 또한, 산소성 및 무산소성 배양 에서만 90주와 53주가 검출되었다. 그러나 이들 90 균주와 53 균주의 동정되지 않은 비율은 비슷하였다(23/90주; $25.5 \%$, 13/53주; $24.5 \%$ ). 배지 종류별 배양 성적은 산소성 및 무산소성 배양 사이의 동정률에 영향을 미치지 않았다(Table 3).

\section{고 찰}

패혈증은 중환자실 내에서 높은 유병률뿐 아니라, 미국에서 중증 패혈증은 인구 10 만 명당 300 례 정도 발생하며 연령에 따 라 빈도가 증가하여 85세 이상의 노인에서는 어린이에 비하여 약 100 배 이상 발생한다. 최근 국내에서 이루어진 다 기관 연구 에서도 중증 패혈증에 의한 원내 사망률은 $34.3 \%$, 중환자실 내 사망률은 29.1\%로 발표되었다[12]. 최근 몇 년 동안 유명인들 이 패혈증으로 인한 급성심부전이나 다발성 장기 부전 등으로 진행돼 사망에 이르게 되면서 패혈증에 대한 사회적 관심이 높 아졌지만, 뇌졸중이나 심근경색증보다 사망률이 높음에도 여 전히 인식 부족으로 인해 폐렴 등 감염병이 패혈증으로 악화하

Table 3. Correct identification rates according to the type of blood culture bottle

\begin{tabular}{lccc}
\hline \multirow{2}{*}{ Result } & \multicolumn{2}{c}{ Adult patients $(\mathrm{N}=235)$} & Pediatric patients $(\mathrm{N}=19)$ \\
\cline { 2 - 4 } \cline { 3 - 4 } & Aerobic & Anaerobic & Pediatric bottle \\
\hline Gram positive bacteria & $76.2 \%(77 / 101)$ & $77.4 \%(55 / 71)$ & $53.3 \%(8 / 15)$ \\
Gram negative bacteria & $88.8 \%(72 / 81)$ & $97.3 \%(72 / 74)$ & $75 \%(3 / 4)$ \\
No identification & $18.1 \%(33 / 182)$ & $11.7 \%(17 / 145)$ & $42.1 \%(8 / 19)$ \\
Misidentification & - & $0.7 \%(1 / 145)$ & \\
No growth & $22.6 \%(53 / 235)$ & $38.3 \%(90 / 235)$ & $57.9 \%(11 / 19)$ \\
Total & $81.8 \%(149 / 182)$ & $87.6 \%(127 / 145)$ & \\
\hline
\end{tabular}


는 경우가 많았다. 이와 같이 패혈증은 다양한 감염증이 동반될 수 있고, 여러 종류의 세균이 원인이 되어 나타나기 때문에 그 원 인균을 규명하기 위해 혈액배양이 필수적이다.

패혈증이나 균혈증 환자는 매우 위험한 상태이므로 혈액배 양을 통한 신속한 세균배양 결과는 환자의 치료에 매우 중요하 며 생존 확률과 연관되어 있다. 최근에는 신속하고 정확한 원인 세균 검출을 위해 자동화 시스템이 도입되고 있다.

이에 본 연구에서는 혈액배양에서 신속한 세균 동정 결과를 얻기 위해 혈액배양 양성에서 계대배양 없이 세균을 Vitek MS 시스템과 Vitek 2 시스템에 직접 접종하였고, 도출된 결과를 표 준법과 비교하여 신뢰도와 정확도를 평가하였다. 본 연구에서 Enterobacteriaceae, GNFB 및 staphylococci에 대한 정확한 동정에 대한 비율은 각각 $97.6 \%, 80.0 \%$ 및 $84.7 \%$ 였다. 그람양 성 균주는 MALDI-TOF MS 시스템으로 다른 검체를 직접법으 로 시행한 방법에서도 상대적으로 낮은 동정률을 보였다[13]. 표준 방법과 비교하여, 직접법은 특히 그람음성 그룹에서 빠르 고 신뢰성 있는 결과를 나타냈다. 이 실험 결과는 그람양성 균주 (64.8 86.3\%)와 그람음성 균주(84 99\%)의 동정의 정확성을 비교할 때, 그람음성 균주의 정확성이 더 높다는 이전의 발표 자 료와 일치한다[14,15]. Vitek MS 시스템의 세균 동정 시 "no identification"결과를 제외하고 직접법과 표준방법의 일치 기 준은 매우 신뢰할 만하며(99.5\%, 207/208), "no identification" 결과의 대부분은 표적슬라이드에 점적한 검체 상태가 좋지 않은 것으로 Vitek MS 시스템에서는 "bad spectrum" 또 는 "not enough peaks"라는 경고 메시지가 나타났다. 이 검사 방법은 CNS와 streptococci의 세균동정에는 한계가 있었다. 직접 MALDI-TOF MS 방법으로 세균 동정 검사를 시도한 다른 프로토콜의 검사 결과와 비교해 보았을 때 CNS는 유사한 결과 (63.3 83.5\%)를 보였다. Monteiro J, Marinach-Patrice C 등은 streptococci와 staphylococci에 의한 MALDI-TOF MS 결과 의 낮은 동정률은 종간의 관련성과 세균 세포벽 조성에 기인한 다고 주장했다[14,15]. MALDI-TOF MS에서 다른 균으로 잘못 동정된 P. acnes에 대해서는 추후 연구가 되어야 할 것으로 사 료된다. 특히 이 세균은 집락에서 직접 검사 시에도 잘못 동정된 경우가 있는 것으로 보고되었다[16]. 무산소성 배양병은 산소 성 배양보다 세균 동정의 정확도가 더 높았지만, 그차이는 통계 적으로 유의하지 않았다. 검체를 준비하는 과정이 무산소성 배 양에서 더 간단하다고 가정하면, 산소성 및 무산소성 배양에서 모두 세균의 증식이 관찰되는 경우 무산소성 배양을 사용하는 것을 추천한다. 이번 실험의 간단한 검체 전처리 방법은 원심분 리만을 사용한 이전 연구(82.2\%)보다 정확한 세균 동정률을 나
타냈다[10]. 소아용 배양에서의 상대적으로 낮은 동정률은 주 로 그람양성균의 원인으로 판단되었다.

본 연구에서는 사슬알균(streptococci)과 혈장응고효소 음 성 포도알균 $(\mathrm{CNS})$ 의 동정 정확도가 그람음성 세균보다 낮았고, 세포벽이 두꺼운 효모양 진균에 대해서는 검사를 진행하지 않 았다. 향후 검사에 사용되는 검체량을 줄이고, 그람양성 세균과 효모양 진균에 대한 동정의 정확도를 높일 수 있는 추가적인 연 구가 필요할 것으로 사료된다. 19개의 소아배양 중 Staphylococcus epidermidis (5), Staphylococcus aureus (1), Staphylococcus saprophyticus (1), Escherichia coli (1), Pseudomonas aeruginosa (1), Neisseriaspp. (1), Micrococcus spp. (1) 등 11개가 정확하게 동정되었으며, Staphylococcus capitis (2), Staphylococcus epidermidis (2), Streptococcus pneumoniae (1), Micrococcus spp. (1), Streptococcus constellatus (1), Burkholderia cepacia(1) 등 8개는 동정되지 않았다.

\section{요 약}

본 연구에서는 계대배양과 세균 동정 시험에 소요되는 시간 을 단축하고, 혈류감염의 새로운 검사 방법을 모색하여 간단하 고 신속 정확한 동정 결과를 도출할 목적으로 질량분석기를 이 용하여 다음과 같은 결과를 얻었다. 혈액배양에서 한 가지 세균 만 배양된 검체는 총 254개였으며, Vitek 2에서 208주(81.8\%) 의 세균을 동정되었으며, 45 주는 동정되지 않았다. 동정된 세균 중 그람양성 세균이 146 개(57.5\%), 그람음성 세균이 108개 (42.5\%)이었다. 전체적으로 233개는 종(species) 수준까지 동 정 되었으며, 21개는 속(genus)수준까지 동정 되었다. 동정 오 류는 Propionibacterium acnes를 Clostridium bifermentans 로 동정 되었다. 균종별로는 enterobacteriaceae, glucose non-fermentative bacilli (GNFB), staphylococci의 정확도 는 각각 81/83 (97.6\%), 12/15 (80.0\%), 72/85 (84.7\%)로 나타 났다. Vitek 2에 의한 표준법과 Vitek MS에 의한 직접법에 의한 동정의 일치율은 $81.8 \%$ 이었으며, 45 주는 동정되지 않았다. 동 정되지 않은 세균들의 대부분은 그람양성 세균( $\mathrm{n}=37)$ 이었고, 그 람양성 세균은 streptococci (14), coagulase-negative staphylococci (CNS) (11), enterococci (3), Staphylococcus aureus (2), Micrococcus spp. (2), Bacillus spp. (2) 그리고 Actinomyces odontolyticus, Finegoldia mag na, Peptostreptococcus spp.가 각각 1건씩 이었다.

결과 보고 시간은 기존의 검사 방법보다 24 72시간까지 단 
축되었다. 산소성 배양과 무산소성 배양 사이의 동정률의 차이 는 없었으나 무산소성 배양을 사용하면 용해 과정이 필요 없어 검체 준비 시간을 단축할 수 있었다. 이상의 연구 결과로 혈액배 양병에서 직접 동정하는 방법은 정확하고 결과 보고 시간이 신 속하여 환자의 치료에 매우 유용할 것이라 생각된다. 향후 추가 적인 연구에서는 본 연구에서 정확성이 부족했던 사슬알균 (streptococci)과 혈장응고효소 음성 포도알균(CNS)을 동정하 기 위한 방법을 더욱 개선할 필요가 있을 것으로 사료된다.

\section{Acknowledgements: None \\ Funding: None \\ Conflict of interest: None}

\section{REFERENCES}

1. Kim WS, Lee HJ. Management of sepsis. J Korean Med Assoc. 2013;56(9):819-826.

2. Martin GS, Mannino DM, Eaton S, Moss M. The epidemiology of sepsis in the united states from 1979 through 2000. N Engl J Med. 2003;348(16):1546-1554.

3. Dellinger RP, Levy MM, Rhodes A, et al. Surviving sepsis campaign: international guid elines for management of severe sepsis and septic shock: 2012. Crit Care Med. 2013;41(2):580-637.

4. Hong SK, Hong SB, Lim CM, Koh YS. The characteristics and prognostic factors of severe sepsis in patients who were admitted to a medical intensive care unit of a tertiary hospital. Koean J Crit Care Med. 2009;24(1):28-32.

5. Kumar A, Roberts D, Wood KE, Light B, Parrillo JE. Duration of hypotension before initiation of effective antimicrobial therapy is the critical determinant of survival in human septic shock. Crit Care Med. 2006;34(6):1589-1596.

6. Machen A, Drake T, Wang YF. Same day identification and full panel antimicrobial sus ceptibility testing of bacteria from positive blood culture bottles made possible by a combined lysis-filtration method with MALDI-TOF VITEK mass spectrometry and the VITEK2 system. PLoS One. 2014;9(2):e87870.

7. Schneiderhan W, Grundt A, Wörner S, Findeisen P, Neumaier
M. Work flow analysis of around-the-clock processing of blood culture samples and integrated MALDI-TOF mass spectrometry analysis for the diagnosis of bloodstream infections. Clin Chem. 2013;59(11):1649-1656.

8. Stevenson LG, Drake SK, Murray PR. Rapid identification of bacteria in positive blood culture broths by matrix-assisted laser desorption ionization-time of flight mass spectrometry. J Clin Microbiol. 2010;48(2):444-447.

9. Romero-Gómez MP, Gómez-Gil R, Paño-Pardo JR, Mingorance $\mathrm{J}$. Identification and susceptibility testing of microorganism by direct inoculation from positive blood culture bottles by combining MALDI-TOF and Vitek-2 Compact is rapid and effective. J Infect. 2012;65(6):513-520.

10. Ling TK, Liu ZK, Cheng AF. Evaluation of the VITEK 2 system for rapid direct identification and susceptibility testing of gram-negative bacilli from positive blood cultures. J Clin Microbiol. 2003;41(10):4705-4707.

11. Chun JW, Jeon HS, Sung HS, Kim MN. Evaluation of MicroScan and Phoenix system for rapid identification and susceptibility testing using direct inoculation from positive BACTEC blood culture bottles. Korean J Lab Med. 2009;29(1):25-34.

12. Kim JH, Hong SK, Kim KC, Lee MG, Jung SS, Choi HS, et al. Influence of full-time intensivist and the nurse-to-patient ratio on the implementation of severe sepsis bundles in Korean intensive care units. J Crit Care. 2012;27(4):414.e11-21.

13. Kim YS, Park KG, Lee KW, Park YJ. Direct identification of urinary tract pathogens from urine samples using the Vitek MS system based on Matrix-Assisted laser desorp tion ionization-time of flight mass spectrometry. Ann Lab Med. 2015;35(4):416-422.

14. Monteiro J, Inoue FM, Lobo AP, Sugawara EK, Boaretti FM, Tufik S. Fast and reliable bacterial identification direct from positive blood culture using a new TFA sample preparation protocol and the Vitek®MS system. J Microibiol Methods. 2015; 109:157-159.

15. Marinach-Patrice C, Fekkar A, Atanasova R, Gomes J, Djamdjian L, Brossas JY, et al. Rapid species diagnosis for invasive candidiasis using mass spectrometry. PLoS One 2010; 5(1):e8862.

16. Coltella L, Mancinelli L, Onori M, Lucignano B, Menichella D, Sorge R, et al. Advancem ent in the routine identification of anaerobic bacteria by MALDI-TOF mass spectrom etry. Eur J Clin Microbiol Infect Dis. 2013;32(9):1183-1192. 